\title{
Effect of Electrical Stimulation in Lower Extremity as Physical Exercise in Type 2 Diabetes Mellitus Patients
}

\author{
Rika Wahyuni Arsianti ${ }^{1, *}$, Dewy Haryanti Parman ${ }^{2}$, Hendy Lesmana ${ }^{2}$, Muhammad Taufiqqurohman ${ }^{3}$ \\ ${ }^{1}$ Department of Electrical Engineering, University of Borneo Tarakan, Jl.Amal Lama No.1, Tarakan, Indonesia \\ ${ }^{2}$ Department of Nurse Science, University of Borneo Tarakan, Jl.Amal Lama No.1, Tarakan, Indonesia \\ ${ }^{3}$ Department of Electrical Engineering, Hang Tuah University, Jl.Arif Rahman Hakim No.150, Surabaya, Indonesia \\ *Corresponding author. E-mail: rkwahyuni@gmail.com
}

Received date: Aug 1, 2017; Revised: Sep 20, 2017; Accepted: Oct 9, 2017

\section{Abstract}

$\mathrm{B}$ ACKGROUND: Type 2 diabetes mellitus (T2DM) is a long-term illness that affects the patient's quality of life and requires substantial health care costs. Lifestyle related to physical exercise is one of the causes of the increasing prevalence of this disease. However, not all T2DM patients can perform physical exercise because very weak physical conditions such as elderly, spinal cord injury or diabetic secondary complications can be contraindicated when physical exercise performed. The aim of this study is to observe the used of electrical stimulation in T2DM patients.

METHODS: The provision of ES to lower extremity muscles was given for 30 minutes in the intervention group.

\section{Introduction}

Physical exercise is one of type 2 diabetes mellitus (T2DM) management care along with education, nutrition therapy and pharmacological intervention. The purpose of physical exercise is to control of blood glucose level. The uptake of glucose in skeletal muscles through glucose trasporter type 4 (GLUT4) is increased when physical exercise performed.(1) Other benefits of physical exercise are to prevent obesity, reduce stress, normalize blood pressure and improve work ability. $(2,3)$ The main source of energy during physical exercise is glucose and lipid. The requirement of glucose and lipid is increased to 15 times when physical exercise is performed and 35 times after 60 minutes.(4) In 2011, The Indonesian Society of Endocrinology stated
Blood glucose samples were taken before and after the ES intervention. The data collected was statistically analyzed by using paired $\mathrm{T}$-test and expressed in mean \pm standard error.

RESULTS: The ES intervention decrease blood glucose level significantly from $193.03 \pm 5.740 \mathrm{mg} / \mathrm{dL}$ to $170.66 \pm 5.200 \mathrm{mg} / \mathrm{dL}(p \leq 0.001)$ in the last session.

CONCLUSION: The effect of ES in lower extremity is shown to be significantly lowers the blood glucose level in T2DM patients.

KEYWORDS: blood glucose, electrical stimulation, physical exercise, type 2 diabetes mellitus

Indones Biomed J. 2018; 10(1): 62-5 that the frequency of physical exercise for management and preventation type 2 diabetes mellitus is 3-4 times a week, 30 minutes duration for each exercise.(5) Regular physical exercise will increase the transport of oxygen, the uptake and uses oxygen in muscles cells. In addition, physical exercise is also able to increase insulin sensitivity, glucose utilization, suppress hepatic insulin resistance and improve lipid metabolism. $(6,7)$ The study of The Finnish Diabetes Prevention showed that the intervention group that did moderate intensity physical exercise for 30 minutes would reduce the risk of diabetes mellitus by $39 \%$.(8) The sensitivity of insulin will decrease if the body doesn't perform physical activities for at least 7 days, especially in the inactive skeletal muscle. $(9,10)$ Therefore physical exercise is highly recommended for T2DM patients in an effort to control blood glucose. 
But not all T2DM patients are able to do physical exercise because of spinal cord injuries (SCI), arthritis, obesity, elderly or patients who must bed rest due to illness. Therefore, the alternative method is needed to replace the physical exercise. The purpose of this study is to investigate the performance of electrical stimulation (ES) as physical exercise to control blood glucose.

ES has been widely used in clinical setting for improving muscle strength, increasing range of motion (ROM), reducing edema, decreasing atrophy, healing tissue and decreasing pain.(11) The study of ES to SCI patients shows the increasing of glucose transporter and insulin sensitivity.(12) The study conducted by Hamada shows that the provision of ES for 20 minutes is able to increase the whole uptake of blood glucose and lasts up to 90 minutes after the provision of ES.(13)

The parameter of ES device must have the same characteristic to signal from Central Nervous System. The parameter consists of frequency, duration and waveform. For clinical application the frequency of $20-50 \mathrm{~Hz}$ is widely used to achieve the optimal result. $(14,15)$ In this study low intensity of exercise are implemented to lower extremities T2DM patients. The parameter of ES device is $20 \mathrm{~Hz}, 200$ $\mu$ s and $50 \%$ duty cycle.

\section{Methods}

This was a quasi-experimental study. Subjects were clinically diagnosed T2DM first stage patients without insulin therapy and complications. Twenty subjects were divided into experimental group and control group. The inclusion criteria were men and women $\geq 35$ years old, random blood glucose $100 \mathrm{mg} / \mathrm{dL} \leq \mathrm{x} \leq 250 \mathrm{mg} / \mathrm{dL}, 1-2$ years duration of diabetes mellitus, BMI $>25 \mathrm{~kg} / \mathrm{m}^{2}$ and willing to sign the informed consent. Exclusion criteria were T2DM patients with hypertension, cardiovascular disease and pregnant women. This study was approved by Ethical Committee from Udayana University (No.383/UN.14.2/KEP/2016).

\section{Sample}

To determine the amount of sample, the analytic comparative was used. The error in type I is 5\% and $10 \%$ for error type II. The value of $Z_{\alpha}$ and $Z_{\beta}$ is 1.64 and 1.28 , respectively. The different $\left(\mathrm{x}_{1}-\mathrm{x}_{2}\right)$ is $23 \mathrm{mg} / \mathrm{dL}$ and standard deviation (SD) is $24 \mathrm{mg} / \mathrm{dL}$. By using the equation below, it was calculated that the amount of sample required is 10 .

$$
n_{1}=n_{2}=\left[\frac{\left(Z_{\alpha}+Z_{\beta}\right) S}{x_{1}-x_{2}}\right]^{2}
$$

\section{Experimental Protocol}

During the experiment, the subjects had breakfast at 07.00 AM with 2 pieces of bread and a cup of tea (26 gr carbohydrate). The subjects come to laboratory at 8.30 $\mathrm{AM}$, and pre-treatment blood sample was taken. Before the treatment was conducted, subjects were asked to supine lying for 10 minutes. The surface electrode was placed in vastus and harmstring muscles for the intervention group. The number of surface electrode in each muscle was 4 . The placement of surface electrode is shown in Figure 1.

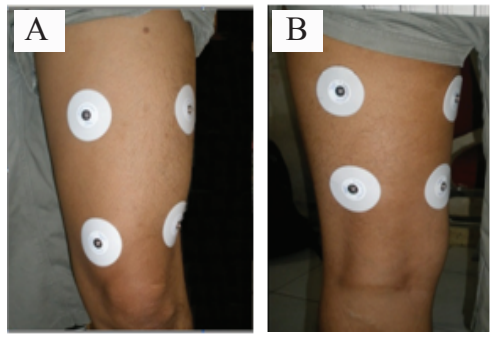

Figure 1. The placement of electrodes in vastus (A) and harmstring (B) muscle.

At 09.00 , the provision of ES was started for 30 minutes. The control group subjects were asked to relaxed sitting for 30 minutes. The pre-treatment and post-treatment blood glucose samples were taken 30 minutes before and after the intervention.(16) The provision of ES is 30 minutes, 3 times a week for 4 weeks. The parameter used in this study is $20 \mathrm{~Hz}, 200 \mu$ s and $50 \%$ duty cycle.

\section{Statistical Analysis}

The data obtained during experiment period was blood glucose before and after the provision of ES. The SigmaPlot12 (Systat Software, London, UK) was used. Paired T-test analysis was performed to investigate the performance of ES for blood glucose control. $P$-value $<0.05$ was considered as statistically significant. Data were expressed as mean \pm standard error (SE).

\section{Results}

The paired T-test analysis showed insignificant decrease in blood glucose values in the control group whereas the significant decrease blood glucose in experiment group. The result of pair T-test is shown in Table 1.

Figure 2 shows that the baseline of blood glucose in first week decreased from $222.93 \pm 5.400 \mathrm{mg} / \mathrm{dL}$ to $206.63 \pm 5.370 \mathrm{mg} / \mathrm{dL}(\mathrm{t}=13.59$ and $p \leq 0.001)$. In second week, the blood glucose decreased from $212.83 \pm 5.33 \mathrm{mg} /$ 
Table 1. The decrement of blood glucose level for control and experiment group.

\begin{tabular}{ccccc}
\hline \multirow{2}{*}{ Week } & \multicolumn{2}{c}{ Control Group } & \multicolumn{2}{c}{ Experiment Group } \\
\cline { 2 - 5 } & Pre-Exp & Post-Exp & Pre-Exp & Post-Exp \\
\hline I & $205.00 \pm 6.254$ & $202.73 \pm 6.275$ & $222.93 \pm 5.400$ & $206.63 \pm 5.370$ \\
II & $202.73 \pm 6.033$ & $199.10 \pm 6.101$ & $212.83 \pm 5.330$ & $196.33 \pm 5.309$ \\
III & $209.50 \pm 6.141$ & $206.67 \pm 6.040$ & $204.30 \pm 5.432$ & $187.93 \pm 5.159$ \\
IV & $206.50 \pm 5.620$ & $200.36 \pm 5.680$ & $193.03 \pm 5.740$ & $170.66 \pm 5.200$ \\
\hline
\end{tabular}

$\mathrm{dL}$ to $196.33 \pm 5.309 \mathrm{mg} / \mathrm{dL}(\mathrm{t}=14.980$ and $p \leq 0.001)$. In the third week, the blood glucose decreased from $204.30 \pm 5.432$ $\mathrm{mg} / \mathrm{dL}$ to $187.43 \pm 5.090 \mathrm{mg} / \mathrm{dL}(\mathrm{t}=14.562$ and $p \leq 0.001)$. In the last session, blood glucose decreased from $193.03 \pm 5.740$ $\mathrm{mg} / \mathrm{dL}$ to $170.66 \pm 5.200 \mathrm{mg} / \mathrm{dL}(\mathrm{t}=11.595$ and $p \leq 0.001)$. This result showed that the effect of electrical stimulation to blood glucose decreased for whole experiment.
A
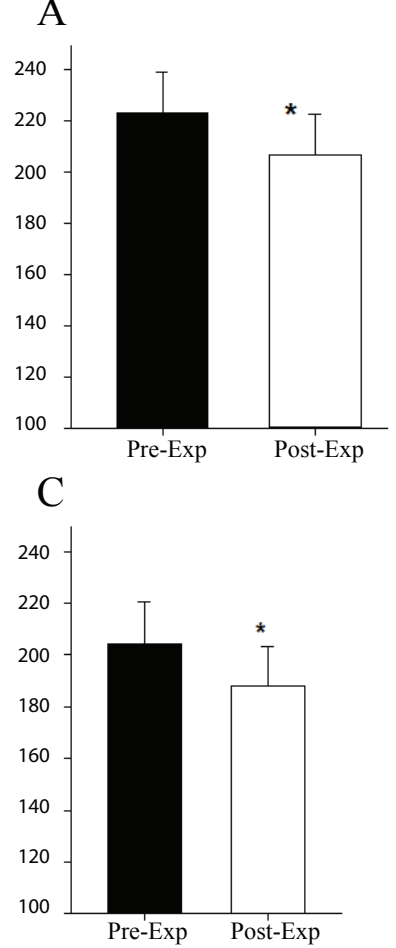

B

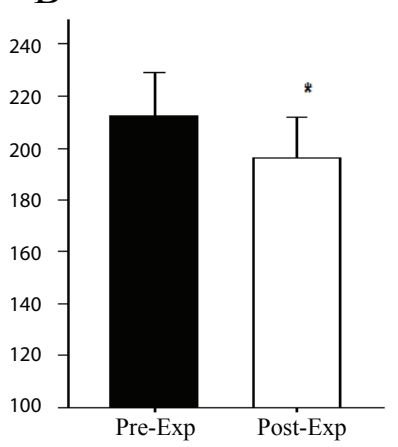

$\mathrm{D}$

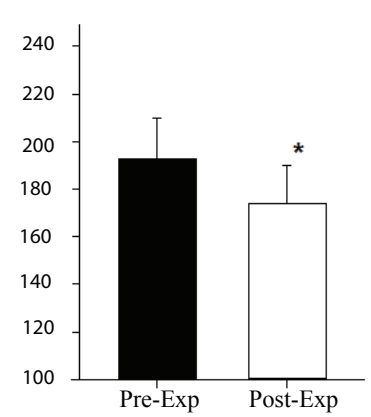

Figure 2. Blood glucose decreased after the ES provision. A: first week ES intervention; B: second week ES intervention; C: third week ES intervention; D: fourth week ES intervention. *significantly different to prior ES $(p<0.001)$

\section{Discussion}

$\mathrm{T} 2 \mathrm{DM}$ is one of chronic diseases that require treatment and cost for long-life term. It affects the quality of life and a substantial increase in health cost, thus management control program is needed. One of control program for T2DM is physical exercise. The life style related to physical activity has an association with diabetes mellitus.(17) Apparently, not all T2DM patients are able to do physical exercise. Therefore, we developed the alternate method to replace physical exercise by using ES device.

A low current delivered to lower extremities muscles through surface electrode to stimulate neuromuscular junction to generate muscle contraction. When muscles contracted, the sensitivity of insulin receptor will increase in the muscle and it causes the activation of receptor that deliver glucose into cell. Therefore the blood glucose will decreased. The accumulation of glycogen due to muscle contraction will reduce blood glucose.(18)

Regular physical exercise can decrease the hemoglobin A1c (HbA1c) significantly. According to The Indonesian Society of Endocrinology physical exercise should be done regularly for 3-5 times a week with low and moderate intensity for 30-60 minutes duration each exercise.(5) Therefore the provision of ES in this study is 30 minutes, 3 times a week for 4 week. Subject's comfort factor is a main consideration for ES device design. The parameters that determine the comfort of subject during underwent ES is the frequency and current.(19,20) In this study we use $20 \mathrm{~Hz}$ frequency of signal impulse because it widely used for clinical application to produce slow muscle contraction without pain.(12) Eleven of 18 subjects complained of pain when given neuromuscular ES (NMES) for a week using a frequency of $35 \mathrm{~Hz}$.(21) Bhadra uses a frequency of $16 \mathrm{~Hz}$ to produce slow contraction at low power levels to prevent discomfort subject and fatique during the provision ES.(22) In this study the subject response from the first week to the fourth week is always recorded. There are no complaint of pain from 10 subjects of intervention group from first to last session during the provision of ES.

The random blood glucose sample before the provision ES was taken. According to inclusion criteria, the random blood glucose allowed to underwent ES is $100 \mathrm{mg} /$ $\mathrm{dL} \leq \mathrm{x} \leq 250 \mathrm{mg} / \mathrm{dL}$. Physical exercise that applied to T2DM with blood glucose level higher than $250 \mathrm{mg} / \mathrm{dL}$ will disturb the uptake of blood glucose in muscle because of the lipid breaking. It is dangerous for body and cold causes comaketoasidosis.(4) T2DM patients with blood glucose level higher than $300 \mathrm{mg} / \mathrm{dL}$ were suggested to delay the physical exercise until it reached the controlled level.(4) Meanwhile, T2DM patients with blood glucose level lower than $100 \mathrm{mg} /$ $\mathrm{dL}$ have minimum risk to hypoglycemia after doing low to moderate intensity physical exercise.(4) 
The aim of diabetes mellitus control program is to increase the quality of life, metabolism control and to prevent the complication of diabetes mellitus. Physical exercise with moderate intensity for 150 minutes a week prevent people to diabetes mellitus about 58\% compare to people with methformin therapy.(23) Physical exercise plays a role in preventing the diabetes mellitus complication and to maintain the quality of life. Therefore the ES can be proposed for T2DM patients who can not perform physical exercise.

\section{Conclusion}

The result of this study shows that the effect of ES in lower extremity is significant in lowering the blood glucose level in T2DM patients. This alternative method is suggested for T2DM with arthritic, SCI and very old patients.

\section{References}

1. Richter EA, Hargreaves M. Exercise, GLUT4, and skeletal muscle glucose uptake. Physiol Rev. 2013; 93: 993-1017.

2. American Diabetes Association. Standards of medical care in diabetes - 2012. Diabetes Care. 2012; 35 (Suppl 1): S11-63.

3. Leutholtz BC, Ripoll I. Exercise and Disease Management. Florida: CRC Press; 2011.

4. Putra ST. Naskah Lengkap PB Persadia. Simposium Diabetes Melitus untuk Dokter dan Diabetisi. Semarang: Diponogoro University; 2004

5. The Indonesian Society of Endocrinology. The Consensus of Control and Prevention of Type 2 Diabetes Mellitus. Jakarta: The Indonesian Society of Endocrinology; 2011.

6. Gormley J, Hussey J. Exercise Therapy: Prevention and Treatment of Disease. New Jersey: John Wiley \& Sons; 2009.

7. Sigal RJ, Kenny GP, Boulé NG, Wells GA, Prud'homme D, Fortier $\mathrm{M}$, et al. Effects of aerobic training, resistance training, or both on glycemic control in type 2 diabetes a randomized trial effects of aerobic and resistance training on glycemic control in type 2 diabetes. Ann Intern Med. 2007; 147: 357-69.

8. Lindström J, Peltonen M, Eriksson JG, Ilanne-Parikka P, Aunola S, Keinänen-Kiukaanniemi $\mathrm{S}$, et al. Improved lifestyle and decreased diabetes risk over 13 years: long-term follow-up of the randomised Finnish Diabetes Prevention Study (DPS). Diabetologia. 2013; 56: 284-93.
9. Stuart CA, McCurry MP, Marino A, South MA, Howell ME, Layne $\mathrm{AS}$, et al. Slow-twitch fiber proportion in skeletal muscle correlates with insulin responsiveness. J Clin Endocrinol Metab. 2013; 98: 2027-36.

10. Mikines KJ, Sonne BE, Farrell PA, Tronier B, Galbo HE. Effect of physical exercise on sensitivity and responsiveness to insulin in humans. Am J Physiol Endocrinol Metab. 1988; 254: E248-59.

11. Doucet BM, Lam A, Griffin L. Neuromuscular electrical stimulation for skeletal muscle function. Yale J Biol Med. 2012; 85: 201-15

12. Gorgey AS, Dolbow DR, Dolbow JD, Khalil RK, Gater DR. The effects of electrical stimulation on body composition and metabolic profile after spinal cord injury-Part II. J Spinal Cord Med. 2015; 38: 23-37.

13. Hamada T, Hayashi T, Kimura T, Nakao K, Moritani T. Electrical stimulation of human lower extremities enhances energy consumption, carbohydrate oxidation, and whole body glucose uptake. J Appl Physiol. 2004; 96: 911-6.

14. de Kroon JR, Ijzerman MJ, Chae J, Lankhorst GJ, Zilvold G. Relation between stimulation characteristics and clinical outcome in studies using electrical stimulation to improve motor control of the upper extremity in stroke. J Rehabil Med. 2005; 37: 65-74.

15. Bowman BR, Baker LL. Effects of waveform parameters on comfort during transcutaneous neuromuscular electrical stimulation. Ann Biomed Eng. 1985; 13: 59-74.

16. Faculty of Medicine, University of Indonesia. Penatalaksanaan Diabetes Mellitus. 9th Ed. Jakarta; University of Indonesia: 2013.

17. Irawan D. Prevalensi dan Faktor Risiko Kejadian Diabetes Melitus Tipe 2 di Daerah Urban Indonesia (Analisa Data Sekunder Riskesdas 2007) [Thesis]. Depok: University of Indonesia; 2010.

18. Forst T, Pfützner A, Bauersachs R, Arin M, Bach B, Biehlmaier H, et al. Comparison of the microvascular response to transcutaneous electrical nerve stimulation and postocclusive ischemia in the diabetic foot. J Diabetes Complications. 1997; 11: 291-7.

19. Baker LL, Wederich C, McNeal DR, Newsam CJ, Waters RL. Neuro Muscular Electrical Stimulation: A Practical Guide. Los Amigos: Research \& Education Institute; 2000.

20. Hamada T, Sasaki H, Hayashi T, Moritani T, Nakao K. Enhancement of whole body glucose uptake during and after human skeletal muscle low-frequency electrical stimulation. J Appl Physiol. 2003; 94: 2107-12.

21. Joubert M, Metayer L, Prevost G, Morera J, Rod A, Cailleux A, et al. Neuromuscular electrostimulation and insulin sensitivity in patients with type 2 diabetes: the ELECTRODIAB pilot study. Acta Diabetol. 2015; 52: 285-91.

22. Bhadra N, Peckham PH. Peripheral nerve stimulation for restoration of motor function. J Clinical Neurophysiol. 1997; 14: 378-93.

23. Mikines KJ, Sonne BE, Farrell PA, Tronier B, Galbo HE. Effect of physical exercise on sensitivity and responsiveness to insulin in humans. Am J Physiol Endocrinol Metab. 1988; 254: E24859. 